\section{1. 自然科学研究の今日・明日}

西欧の気候風土、精神風土を背景に培われ た自然科学は、自然観の普遍的原理への回帰 と確認の繰り返しを行いつつ、初期の頃の巨 視的な、全体的な形から、次第に物理学、化 学や生物学等に分化しつつ、約 3 世紀に亘る 間に我々の周囲の物質や、そこで起こってい る自然現象等に対する理解を深めていった。

こうして成長して来た近代科学の流れは巨視 的な決定論的な自然観に導かれて、自然のし くみを機械論的に受けとめ、二元論的に考之 る思潮に強く影響され、人間優位の立場がと られて来た。

20世紀の初頭に到って、物理学の分野で生 れた相対論ならびに量子論はそれまでの自然 観を大きく変える源となり、その波及効果は 精密な実験や自然観測の技術の成長と相俟っ て、物質の多様な系を取り扱う化学の分野の 現象の理解に、そして更により多様な系であ る生物学や地学の研究にも広がっている。

すなわち、宇宙の起源や構造といったス ケールの大きな自然から物質の本質にせまる 極限微小領域の自然までを構成する諸要素存 在の基本原理の解明への努力が行なわれ、

個々の物質については化学結合、構造、物性 や反応についての理解が微視的自然観に基づ いて進むとともに、物質設計、物質合成の試 みは次第に高次構造化の方向に進み、無機体、 有機体を通して新規な物質が創製されるよう になった。そしてわれわれは時に、高温超伝 導体のように自然の中に潜むこれまでの秩序 を越えた営みの現れに遭遇している。生物科 学の分野では遺伝子の本体が生体高分子の
池田重 良

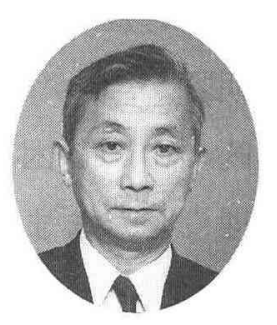

DNA であることが明らかになって、さらに その立体構造が決定された。このような分子 生物学的研究から遺伝子の機能が解明され、 これによって遺伝現象をDNA とその塩基配 列で理解する方向の研究が展開された。そし て、遺伝子の構造が下等生物から高等生物に 到るまで極めてよく保存されていることが明 らかとなった。この事実は生物の起源がひと つであり、この生体高分子の持つ遺伝情報が 生命の秩序を支配する基であるということを 意味するもので、これはこれまでの生命観に 画期的な変化をもたらした。今ヒトゲノムの 解読と云う膨大な仕事が国際的に行なわれて いることはよく知られていることである。 また地球科学の分野では、プレートテクト ニクス説は地球の進化のダイナミクスを解明 する新しい理念として、約30年前に現れたが、 これによって地球科学に関係する学問分野の 自然観は大きな影響を受けたが、更に新しい 知見が加えられようとしている。地球科学、 天文学、海洋科学や気象学そして生物学では 世界に広がる共同野外観測研究が盛んに行な われている。

自然科学の他の分野も同じように地道な研 究を積み上げて発展を遂げて来てる。このよ うにしてこれまで主に自然を構築している諸 要素を解明し、それによって出来ている秩序 ある自然のしくみの理解に努めてきた自然科

池田重良（いけだしげろう 1924年生）

日本学術会議第 4 部会員、化学研究連絡委員会委 員、分析化学専門委員会委員長、大阪大学名誉教授、 立命館大学:客員教授、理学博士 専門：化学 
学は、これからも未知の要素の探求を続ける ことには変わりはないが、一方で大自然の秩 序形成や変化のプロセスのいろいろの段階で 非決定論的要素が入っていることをしばしば 見出していた。地球の奥のマグマの活動、宇 宙の構成の核融合反応、生物の代謝作用、植 物の同化作用、開放系の化学反応等はいずれ もこのようなプロセスを含んでいて自然の営 みに重要な役割を果たしている。このように 外部と常につながりを持った開放系の非平衡 な状態を自然の散逸構造と位置づけられてい る。このような複雑な自然の営みをどこまで 自然科学として理解していくことが出来るか がこれからの課題である。原子・分子から生 命へ、極微の世界から宇宙へと諸科学の相関 を究め、複雑な自然を自然の姿のまま理解す る見方の研究がわが国でも既に進められてい る。

しかし、一方ではまだまだ自然の中には未 知の要素が多い。それらは、自然のありのま まを理解するために是非必要である。科学と してはこれからも個々の物質や現象の問題を 地道に研究して行く努力も続けていかなくて はならない。

分子設計の研究は物質科学の分野では早く から行なわれ、物質創製が行なわれているこ とは前にも述べたが、物性物理系でも物質設 計の研究は進んでおり、生物学で行なわれて いる生物機械の研究ではわが国は世界をリー ドしているといってよかろう。脳科学研究の 進歩も入れて、自然科学では自然の仕組み、 振る舞いの研究から営みの研究に入ってい る。

自然科学の研究と環境との関わりは当然の ことながら強く深い。実在の自然は定常的な 存在に見えるが実際には常に変化している。 前にも触れたようにその自然を支えているの が、地球の奥のマグマ、恒星の核融合反応、
微生物、植物や動物の代謝作用等である。そ してこれらに支えられた自然界における物質 循環を考えると、われわれの地球環境の人為 的歪みの発生は社会的に大きな傷害である が、それが回復しても、学術的には恐ろしい 事件であると受け取るべきである。長い時間 をかけて緅られる自然の歴史の中に異常な変 化の記録を残すことになる。今、自然科学の 多くの分野で、地球環境に関する研究を集中 的に、学際的にかつ国際的に取り上げている のは当然のことで、わが国の研究者も積極的 にこれに参加しているが、さらにその先導的 役割を果たせるよう、精神的、経済的な面を 加えての大きな支援が必要であろう。

\section{2. 自然科学研究と応用自然科学研究}

自然科学の発展は科学者の知的欲求の熱意 と地道な研究によって得られるものである が、そこでは技術の働きが大きな役割を果た していることは誰もが認めることである。今 世紀の自然科学の研究は技術の向上によって 導かれたといえる。科学技術と云う言葉は自 然科学の成果と技術の強い相互作用によって 生れた技術と解釈出来よう。ここでわれわれ は、純粋な自然科学の研究と科学技術との間 に存在する応用自然科学研究の位置づけを明 確にすべきではなかろうか。この自然の科学 的研究と技術との間の相互作用の役割を務め るのが応用自然科学研究である。ここであ之 て応用自然科学研究という言葉を使ったの は、これを自然科学研究の延長上に位置する 基礎科学と考えたいためである。応用自然科 学研究に於いては、自然から得た知識の選択 と変換、人類の中に生れ、育った知恵との融 合が行なわれる。応用自然科学の自然観には 人間の価值観が入る。そこから新しい科学技 術の方法論が作られるが、また新しい現象や 物質が見出されることが多い。自然現象の人 


\section{工実験の場である。}

数学は元来自然科学とは別で、純粋な人間 の思考の資産である。しかしその研究成果の 自然科学への波及効果は大きい。電子計算器 は自然科学研究の方法論として離すことの出 来ないものの一つとなっている。もともと応 用数学と応用物理学から生れ育ったのかもし れないが、今では独自の論理体系を展開して 計算器科学として独立した席をしめるまでに 発展して来ている。脳の科学の研究に見られ るように自然科学、応用科学の諸分野の研究、 さらには人文科学や社会科学の諸学問にかか わる総合的な学術研究の分野と考えられよ う。多様な自然の複雑さを理解しようとする、 これからの自然科学研究の展開を考えると情 報論的自然観が生れてくるかも知れない。

\section{3. 自然科学研究の推進について}

これまでの自然科学の研究は分化された個 別の学門分野がさらに専門分化を進めて発展 してきたが、研究の対象が広がって、複雑に なって来るにつれて、多様でいろいろな知識 が積み上げられてこそ総合した自然理解が深 められると云う意識が広がって来た。このよ うな研究の在り方の変化はおのずから学際的 研究や国際的研究を促進し、また学術研究組 織もそれに応じて変化して来る。その結果、

例之ば宇宙科学、物質科学、生命科学といっ た学問組織の形成が自然発生的に出来上がっ て来た。その時でも学問としての基礎は変わ らない。学際化は研究対象によって流動的で ある。国際化は自然科学研究の性格から云っ て普遍的なことは当然であろう。しかし国情 や歴史的背景などによって実情は異なってく る。国際貢献や国際交流のこともあるが、優 れた研究者の受け入れについて考えると、研 究自体の幅と深さに変化をもたらすばかりで なく研究環境の国際化すなわち研究態勢の開
放性の向上、残存する封建的性格を取り除く ことにも役立つ。そして自然科学研究の国際 共同研究の発進を促進する。科学技術基本法 が設立されて、わが国でも科学の基礎研究重 視の政策が打ち建てられた。これによってい ろいろな形での研究助成がかなり増加して来 ている。研究室の改善はともかく、研究に必 要な費用を得る機会は多くなって来た。これ に時間的ゆとりを加之れば研究環境は相当改 善されることになろう。それだけに、研究者 の自覚が望まれる。自然科学の研究も多岐に 渡り、幅広く展開されている。研究が研究者 の知的欲求から発したものであるとしても、 知的重みが大きく、新規性が高く、学術的に 波及効果の高いことが期待出来そうな研究の 場合に、戦略的に研究を推進する必要がある ことは云うまでもない。何よりも夢を持った 研究を如何に掘り出すかである。自然観の転 換にかかわるような発想もはじめは小さな個 別的研究から芽生えることを考之ると萌芽的 研究の評価の重要性をひしひしと感じる。

\section{4. 文化としての自然科学}

自然科学の研究が高価な支援を受けなが ら、研究の内容は実社会の多くの人々には直 接役に立たない知的活動になって行くことを 憂えた科学者の記述を見たことがある。たし かに純粋な自然科学の研究からすぐに実社会 に役立つような新しい技術が生れるとは限ら ない。しかし、科学と技術の相互作用の強く なったこの頃では、科学技術と云う言葉があ るように直接、間接そして時間を問わなけれ ば自然科学の成果の技術的有用性は極めて高 いことは、電子技術や遺伝子科学技術等を見 れば明らかである。

物理学の研究成果によれば、われわれの存 在を可能にした宇宙の生成、そしてそこに存 在するもつとも普遍的な基本の自然法則やそ 
の生成に到る初期条件は実に神秘に富んでい るという。ここに発見された基本定数は生物 の存在に非常に都合の良い特殊な自然を与え るものであるという。このような特殊な条件 の基に生れた生命を知った時、多くの人々は その自然を破壊する行為を慎むようになるで あろう。この他例えば、光とは何か、物質の 構造は、人類の歴史は、柿の葉の色はどうし て変わるか、といった問いに対して自然科学 は正しく答えて来た。20世紀の今日まで、分 けられてきた自然の要素と、見出された秩序 と存在の理法とで描かれていく知識体系はわ れわれの視覚で直接感じる自然とは違った姿 を持っている。これから 21 世紀へ向けて、自 然の複雑さの理解が深まると更にその特殊な 姿や振る舞いが描かれてくることであろう。

これらは科学者の自然へ知的欲求の熱意と地 道な努力によって得られるものであるがこの ような知識を専門の集団だけで享受すべきも のではない。自然科学の研究の成果はすべて の人の知的資産ということを自覚して、出来 るだけ多くの人が科学を楽しみ、深い自然の 美しさを享受出来る方策を構築すべきであ る。人文科学と同じように社会の人々の知的 生活を豊かにする文化としての自然科学の在 り方を模索することは、社会から、高価な支 援を受けて研究を続ける場を与えられている 者の務女と考えるべきである。自然科学者の 描いた自然観が、人文科学、社会科学の分野 の人々の世界観にも影響を及ぼしているので はなかろうか。それだけに、自然科学研究の 価值観は広く問われるべき時代であろう。人 間の自然認識の欲求のために自然を破壊する と云う過ちを犯すことのないように、自然科 学研究の在り方を考え、その社会的価值観を
論じる場合、人文科学的思考、特に風土を背 景とした地域の性格が現れて来るのではなか ろうか。

化石資料をはじめとする地質鉱物資料や生 物の標本資料はこれらの自然科学部門の研究 資料として有用であるのみならず、多くの人 が自然の歴史に触れることの出来る資産であ る。巨大科学や応用科学が広がる中で、野外 観察や標本資料に根ざす学問をより盛んにす ることは、自然科学の研究の流れの中に自然 の階層構造を、部分から全体へとベクトルを 向けつつある部分が出来て来ていることと考 之合わせて必要なことである。わが国独自の 構想で特色ある世界的に順位の高い自然史館 を作り多くの文化的価値の高い資料と学者を 集めて、国の内外からの見学者を受け入れる ことを是非実現させたい。同じようなことは 物理・化学系を主体とする科学館あるいは科 学博物館についても望みたい。最近わが国で も中央ばかりでなく、各地域でもこのような 施設が増加していることは喜ばしいことであ る。若い人々にゆとりをもって自然科学の歴 史のなかの旅をさせ、また、科学技術の発達 の過程をたどらせることは非常に刺激となる ことであろう。そこを離れても自然科学に対 するイメージが残り、それが後に自然科学へ の道を選ばせ、またその道で発想の相転移を 起こさせる動機となるのではなかろうか。海 外から多くの人々が訪ねてきて、優れた人物 がわが国に留まって研究することを望むよう になり、開かれた科学者の交流を促進する動 機も増えよう。世界に誇るべき内容を備え、 ゆとりある空間の中で多くの人々が自然の歴 史、文化としての科学の資産を享受出来るよ うにしたいものである。 